\title{
Pengaruh Metode Pembelajaran dan Motivasi Belajar Siswa terhadap Hasil Belajar Bahasa Indonesia
}

\author{
Juwariah \\ Fakultas Pascasarjana, Universitas Indraprasta PGRI \\ Jalan Nangka No. 58 C/TB. Simatupang, Tanjung Barat, Jakarta Selatan 12530 \\ mpdjuwariah@gmail.com
}

\begin{abstract}
The purpose of this research is to know: 1) The influence of learning method on the learning result of Indonesian students of Private Junior High School in Indramayu Regency. 2) The influence of motivation on the learning result of Indonesian Private Junior High School students in Indramayu District. 3) Effect of learning methods and learning motivation on Indonesian language learning outcomes of private junior high school students in Indramayu Regency. The sample used 60 students as the research sample using a proportional random sampling technique from all class VII private junior high schools in Indramayu Regency. Data collection was done by giving the concept comprehension test and questionnaire distribution. Data analysis consisted of testing research instruments with normality test and homogeneity test. Hypothesis testing with 2 paths Anova test. This study was conducted in May 2018. Based on the results of the hypothesis and data analysis, it is concluded that the following things are as follows: 1) There is a significant influence of the learning model on Indonesian language learning outcomes in private junior high schools in Indramayu District. This is evidenced by the acquisition of Sig. $=0.007<0.05$ and $\mathrm{Fh}=7.791 .2$ ) There is a significant effect of learning motivation on the results of Indonesian language learning in private junior high schools in Indramayu Regency. This is evidenced by the acquisition of Sig. = $0.000<0.05$ and $\mathrm{Fh}=34.722 .3$ ) There is a significant interaction effect on the learning model and learning motivation on the results of Indonesian language learning in private junior high schools in Indramayu Regency. This is evidenced by the acquisition of Sig. $=0.034<0.05$ and $\mathrm{Fh}=4.713$.
\end{abstract}

Keywords: Indonesian language learning outcomes, learning methods, learning motivation

\begin{abstract}
Abstrak
Tujuan penelitian ini adalah untuk mengetahui: 1) Pengaruh metode pembelajaran terhadap hasil belajar bahasa Indonesia siswa SMP Swasta di Kabupaten Indramayu. 2) Pengaruh motivasi terhadap hasil belajar bahasa Indonesia siswa SMP Swasta di Kabupaten Indramayu. 3) Pengaruh metode pembelajaran dan motivasi belajar terhadap hasil belajar bahasa Indonesia siswa SMP Swasta di Kabupaten Indramayu. Sampel yang digunakan 60 siswa dengan teknik proposional random sampling dari seluruh kelas VII SMP Swasta di Kabupaten Indramayu. Pengumpulan data dilaksanakan dengan pemberian tes pemahaman konsep dan penyebaran angket. Analisa data terdiri dari pengujian instrumen penelitian dengan uji normalitas dan uji homogenitas. Pengujian hipotesis dengan uji Anova 2 jalur. Hasil penelitian menunjukkan: 1) Terdapat pengaruh yang signifikan model pembelajaran terhadap hasil belajar Bahasa Indonesia di SMP Swasta di Kabupaten Indramayu. Hal ini dibuktikan dengan perolehan $\mathrm{Sig}=0,007<0,05$ dan $\mathrm{Fh}=7.791$. 2) Terdapat pengaruh yang signifikan motivasi belajar terhadap hasil belajar Bahasa Indonesia di SMP Swasta di Kabupaten Indramayu. Hal ini dibuktikan dengan perolehan Sig $=0.000<0.05$ dan $\mathrm{Fh}=34.722$. 3) Terdapat pengaruh interaksi yang signifikan model pembelajaran dan motivasi belajar terhadap hasil belajar Bahasa Indonesia di SMP Swasta di Kabupaten Indramayu. Hal ini dibuktikan dengan perolehan Sig. $=0,034<0,05$ dan $\mathrm{Fh}=4.713$.
\end{abstract}

Kata Kunci: Hasil belajar bahasa Indonesia, metode pembelajaran, motivasi belajar.

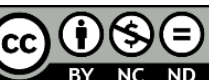

Creative Commons Attribution-NonCommercial-NoDerivatives 4.0 International License 


\section{PENDAHULUAN}

Dalam pendidikan formal dan nonformal perkembangan kemampuan yang telah dicapai oleh anak didik dalam satu semester apabila anak didik mendapatkan nilai yang bagus dalam rapornya, maka bisa dikatakan anak tersebut bisa berhasil dalam belajarnya dan proses belajar-mengajar berjalan dengan baik. Namun, sebaliknya, apabila nilai rapornya rendah, maka belajar-mengajar mengalami kegagalan. Prestasi merupakan unsur penting dalam dunia pendidikan karena digunakan untuk mengukur sejauh mana keberhasilan proses belajar mengajar yang telah dilakukan. Dengan berdasarkan prestasi yang dicapai oleh anak didik, lembaga pendidikan dapat mengevaluasi apakah proses belajar mengajar yang telah dilaksanakan berhasil dan melakukan pembaruan-pembaruan dalam sistem pendidikan. Selain itu, prestasi belajar juga dapat digunakan untuk memotivasi siswa agar berusaha lebih giat lagi. Dengan mengetahui hasil yang telah dicapainya siswa akan terpacu untuk berusaha menjadi yang lebih baik lagi. Prestasi belajar dipengaruhi oleh dua faktor, yaitu faktor intern dan faktor ekstern. Faktor intern adalah faktor yang berasal dari dalam diri siswa, di antaranya kecerdasan, minat, bakat, motivasi, dan lain-lain.

Pendidikan akan berupaya dalam mencerdaskan kehidupan bangsa, lembaga ini telah melakukan upaya untuk menciptakan lingkungan yang kondusif, berbagai fasilitas yang mendukung proses belajar-mengajar, dan menyediakan tenaga pendidik yang berkompeten. Akan tetapi, prestasi siswa dalam mata pelajaran bahsa Indonesia bisa dikatakan belum memuaskan. Dari beberapa faktor yang memengaruhi hasil belajar di atas peneliti ingin meneliti tentang kontribusi metode pembelajaran dan motivasi belajar terhadap hasil belajar bahasa Indonesia yang tertuang dalam rapor. Faktor ektern adalah faktor yang berasal dari luar diri siswa, di antarannya lingkungan keluarga, lingkungan sekolah dan lingkungan masyarakat.

Kenyataan yang terjadi dalam lembaga pendidikan pada saat ini masih banyak siswa yang prestasinya tergolong rendah. Tidak terkecuali dalam mata pelajaran bahasa indonesia. Pelajaran bahasa Indonesia merupakan salah satu dari mata pelajaran yang diberikan pada siswa Sekolah Menengah Pertama (SMP). Bahasa Indonesia termasuk salah satu pelajaran yang sulit sehingga membutuhkan ketekunan dan semangat yang tinggi untuk mempelajarinya. Selain pelajarannya yang tergolong sulit, terkadang guru yang mengampu mata pelajaran tersebut terkadang keras dan berdisiplin tinggi sehingga tercipta suasana belajar yang menegangkan yang mengakibatkan siswa merasa takut atau menjadi bosan. Akhirnya pencapaian hasil belajar yang kurang maksimal. Dalam penelitian ini objek penelitiannya adalah siswa kelas VII SMP Swasta di Kabupaten Indramayu.

Dalam kurikulum tingkat satuan pendidikan Sekolah Menengah Pertama mata pelajaran Bahasa Indonesia menyebutkan bahwa salah satu standar kompetensi untuk siswa kelas VII semester dua, adalah mengungkapkan pikiran dan perasaan secara lisan dalam diskusi untuk mengapresiasi drama. Namun, pencapaian kompetensi dasar yang terkait dengan kemampuan berbahasa dengan hafal, intonasi, dan ekspresi yang tepat masih rendah. Nilai rata-rata yang dicapai 
oleh sebagian besar siswa kurang dari 70 yang merupakan batas kreteria ketuntasan minimal (KKM) (hasil wawancara dengan guru kelas dan Observasi).

Proses pembelajaran masih dilaksankan guru dengan metode ceramah. (Hasil Wawancara dengan guru kelas). Kondisi pembelajaran seperti ini justru membuat siswa semakin" tenggelam" dalam kepasifan. Mereka belajar tidak lebih dari rutinitas, bukan suatu kebutuhan, sehingga mereka kurang tertantang terlibat secara aktif dalam proses belajar mengajar. Siswa cenderung belajar secara individual, menghafal konsep-konsep yang abstrak dan teoretis.

Proses pembelajaran yang baik ditandai oleh tiga hal, yaitu (1) tingkat partisipasi dan jenis kegiatan belajar yang dihayati siswa, (2) peran guru dalam proses belajar mengajar, dan (3) suasana proses pembelajaran. Makin intensif partisipasi dalam kegiatan belajar mengajar, maka makin tinggi kualitas proses belajar itu. Mengacu pada pandangan di atas, dapat dikatakan bahwa kondisi pembelajaran bahasa Indonesia yang selama ini dilaksanakan di SMP Swasta di Kabupaten Indramayu dapat dikatakan belum baik, sebagaimana telah digambarkan di atas yakni pembelajaran masih berkiblat pada guru, guru yang lebih aktif, sementara peran aktif siswa belum maksimal.

Tujuan metode kooperatif adalah (a) menumbuhkan rasa tanggung jawab dan keberanian dalam proses pembelajaran, (b) memupuk sikap gotog royong, toleransi, kepekaan sosial, sikap demokratis, saling menghargai, dan memupuk keterampilan mengadakan interaksi sosial, (c) menumbuhkan motivasi belajar siswa, dan (d) menumbuhkan jiwa kompetitif siswa (Lie, 2005, pp. 32-35).

Pembelajaran kooperatif merupakan suatu perangkat prosedur pengajaran yang digunakan agar siswa belajar dalam suatu kelompok untuk mencapai tujuan bersama. Tujuannya adalah untuk membangkitkan interaksi personal di dalam kelompok melalui diskusi. Dalam hal ini aktivitas pembelajaran berpusat pada siswa. Mereka mendengarkan penjelasan guru, mempelajari materi ajar, berdiskusi, melaporkan, bertanya jawab, dan memberikan kesimpulan materi yang didiskusikan.

Berdasarkan uraian di atas, maka peneliti merasa perlu untuk meneliti penerapan metode kooperatif jigsaw sebagai sarana untuk meningkatkan kemampuan apresiasi drama. Oleh sebab itu, penelitian ini akan mengkaji tentang pengaruh metode pembelajaran dan motivasi belajar terhadap hasil belajar kelas VII SMP Swasta di Kabupaten Indramayu."

\section{METODE}

Tempat penelitian adalah di Sekolah Menengah Pertama Swasta di Kabupaten Indramayu, yaitu SMP Pembangunan Tukdana, SMP Pembangunan Lelea, dan SMP Pembangunan Sukagumiwang. Waktu penelitian dilakukan mulai dari tahap persiapan sampai dengan penyelesaian yaitu sekitar bulan Maret 2018 sampai dengan Juli 2018.

Menurut (Sugiyono, 2008: 6), metode penelitian pendidikan dapat diartikan sebagai cara ilmiah untuk mendapatkan data yang valid dengan tujuan dapat digunakan untuk memahami, memecahkan dan mengantisipasi masalah dalam bidang pendidikan. Menurut (Ibnudin, 2018) metode penelitian merupakan cara 
ilmiah dalam mencari dan mendapatkan data serta memilihkaitan dengan prosedur dalam melakukan penelitian dan teknis penelitian.

Metode yang digunakan dalam penelitian ini adalah metode eksperimen. Untuk menjawab permasalahan dalam penelitian ini digunakan pendekatan korelasional dengan menggunakan analisis Varians Treatment by Level. Untuk mempermudah memahami konsep penelitian yang dilakukan, proses pelaksanaan penelitian pengaruh penggunaan metode pembelajaran dan motivasi belajar.

Menurut (Sugiyono, 2008: 18) bahwa "sampel adalah bagian dari jumlah dan karakteristik yang dimiliki oleh populasi tersebut". Sugiyono menambahkan bila populasi besar, dan peneliti tidak mungkin mempelajari semua yang ada pada populasi, misalnya karena keterbatasan dana, tenaga, dan waktu, maka peneliti dapat menggunakan sampel dari populasi itu. Dalam penelitian ini pengambilan sampel, digunakan teknik random sampling yaitu mengambil sampel secara acak dari dua sekolah yang menjadi populasi penelitian ini yaitu siswa di SMP Swasta di Kabupaten Indramayu. Sampel penelitian adalah siswa kelas VII SMP.

Teknik sampling yang digunakan dalam penelitian ini adalah dengan menggunakan probility sampling dengan teknik simple random sampling. Menurut (Saksomo, 2004: 59) menyatakan "simple random sampling adalah pengambilan anggota sampel dilakukan secara acak tanpa memperhatikan strata yang ada dalam populasi". Artinya semua anggota populasi mempunyai peluang yang sama dan tidak terkait untuk dimasukan ke dalam sampel.

Dalam penelitian ini instrumen yang digunakan dalam pengumpulan data adalah perlakuan (treatment) dan tes. Perlakuan digunakan untuk mengumpulkan data variabel bebas pertama (X1) yaitu penggunaan metode pembelajaran, sedangkan tes pilihan ganda digunakan untuk mengumpulkan data variabel bebas kedua (X2) yaitu motivasi belajar. Selanjutnya tes esai digunakan untuk mengumpulkan data variabel terikat (Y) yaitu Kemampuan menyimak bahasa Indonesia.

Menurut (Sugiyono, 2008: 148) mengatakan bahwa "instrumen penelitian adalah suatu alat yang digunakan untuk mengukur fenomena alam maupun sosial yang diamati”. Sebagaiman dijelaskan sebelumnya, bahwa ada dua jenis data yang dikumpulkan dalam penelitian ini.

\section{HASIL DAN PEMBAHASAN}

Penelitian ini merupakan penelitian yang terdiri dari dua faktor bebas, yaitu faktor model pembelajaran (A) dan motivasi belajar (B). Masing-masing faktor terdiri dari sub faktor yang disebut level. Untuk model pembelajaran (A) ada dua, yaitu Jigsaw $\left(A_{1}\right)$ dan Konvensional $\left(A_{2}\right)$. Faktor kedua adalah motivasi belajar $(B)$ dengan dua level, yaitu: tinggi $\left(\mathrm{B}_{1}\right)$ dan rendah $\left(\mathrm{B}_{2}\right)$.

\section{Data Hasil Belajar Bahasa Indonesia yang Menggunakan Model Pembelajaran Jigsaw (A1)}


Tabel 1. Deskripsi Data Penelitian Hasil Belajar Bahasa Indonesia yang Menggunakan Model Pembelajaran Jigsaw

Statistics

Hasil Belajar Bahasa Indonesia yang Menggunakan Model Pembelajaran Jigsaw

\begin{tabular}{|c|c|c|}
\hline \multirow{2}{*}{$\mathrm{N}$} & Valid & 30 \\
\hline & Missing & 30 \\
\hline Mean & & 82.17 \\
\hline Median & & 80.00 \\
\hline Mode & & 80 \\
\hline Std. Deviation & & 8.972 \\
\hline Minimum & & 65 \\
\hline Maximum & & 95 \\
\hline
\end{tabular}

Dilihat dari hasil perhitungan di atas, maka bisa dikatakan bahwa hasil belajar Bahasa Indonesia yang menggunakan model pembelajaran Jigsaw di SMP Swasta di Kabupaten Indramayu tergolong tinggi. Hal ini di indikasikan dengan perolehan nilai rata-rata sebesar 82.17.

Untuk memperjelas data di atas, dijelaskan dalam histogram sebagai berikut

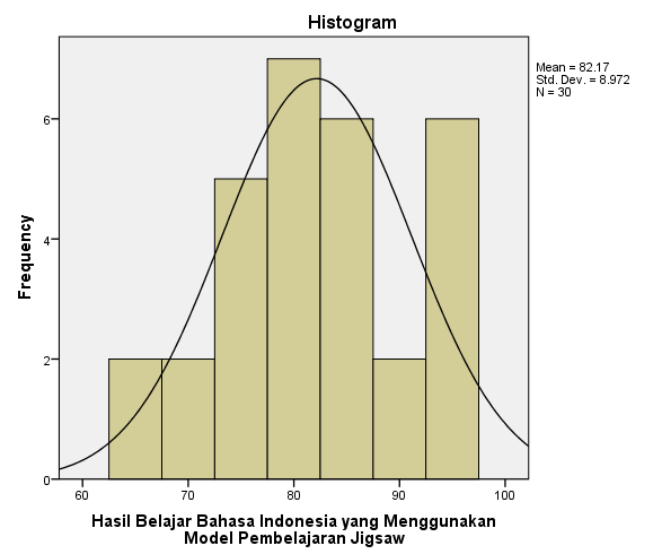

Gambar 1. Histogram Poligon Variabel Hasil Belajar Bahasa Indonesia yang Menggunakan Model Pembelajaran Jigsaw

Data Hasil Belajar Bahasa Indonesia yang Menggunakan Model Pembelajaran Konvensional (A2)

Tabel 2. Deskripsi data Penelitian Hasil Belajar Bahasa Indonesia yang Menggunakan Model Pembelajaran Konvensional

\section{Statistics}

Hasil Belajar Bahasa Indonesia yang Menggunakan Model Pembelajaran Konvensional

\begin{tabular}{|l|l|l|}
\hline \multirow{2}{*}{$\mathrm{N}$} & Valid & 30 \\
\cline { 2 - 3 } & Missing & 30 \\
\hline Mean & 77.67 \\
\hline Median & 77.50 \\
\hline
\end{tabular}




\begin{tabular}{|l|l|}
\hline Mode & 75 \\
\hline Std. Deviation & 6.915 \\
\hline Minimum & 65 \\
\hline Maximum & 95 \\
\hline
\end{tabular}

Dilihat dari hasil perhitungan di atas, maka bisa dikatakan bahwa hasil belajar bahasa Indonesia yang menggunakan model pembelajaran Konvensional di SMP Swasta di Kabupaten Indramayu tergolong cukup. Hal ini diindikasikan dengan perolehan nilai rata-rata sebesar 77.67. Untuk memperjelas data di atas, dijelaskan dalam histogram sebagai berikut:

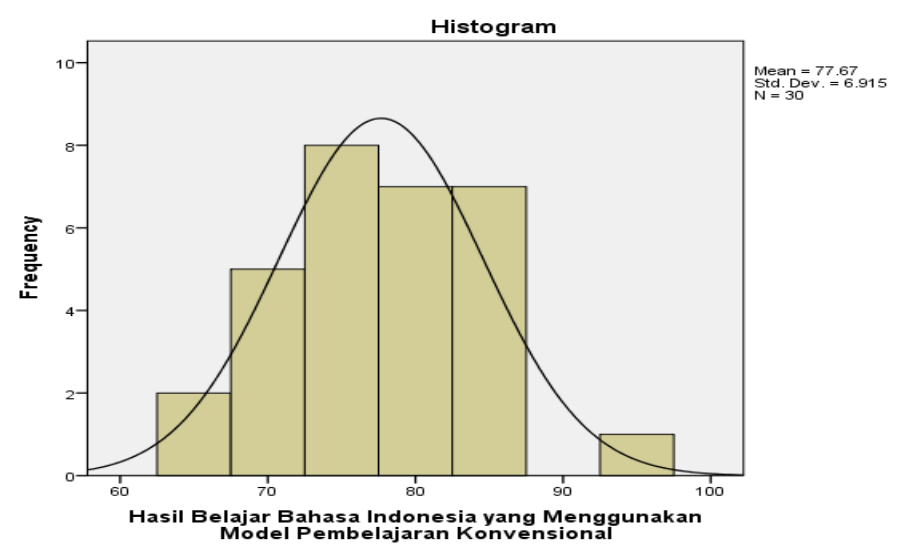

Gambar 2. Histogram Poligon Variabel Hasil Belajar Bahasa Indonesia yang Menggunakan Model Pembelajaran Konvensional

Data Hasil Belajar Bahasa Indonesia yang Memiliki Motivasi Belajar Tinggi (B1)

Tabel 3. Deskripsi Data Penelitian Hasil Belajar Bahasa Indonesia yang Memiliki Motivasi Belajar Tinggi

\section{Statistics}

Hasil Belajar Bahasa Indonesia Siswa yang Memiliki Motivasi Belajar Tinggi

\begin{tabular}{|c|c|c|}
\hline \multirow{2}{*}{$\mathrm{N}$} & Valid & 30 \\
\hline & Missing & 30 \\
\hline Mean & & 84.67 \\
\hline Median & & 85.00 \\
\hline Mode & & 85 \\
\hline Std. Deviation & & 7.303 \\
\hline Minimum & & 70 \\
\hline Maximum & & 95 \\
\hline
\end{tabular}


Bila dilihat dari hasil perhitungan di atas, maka bisa dikatakan bahwa Hasil Belajar Bahasa Indonesia yang memiliki motivasi belajar tinggidi SMP Swasta di Kabupaten Indramayu tergolong tinggi. Hal ini di indikasikan dengan perolehan nilai rata-rata sebesar 84.67. Untuk memperjelas data di atas, dijelaskan dalam histogram sebagai berikut:

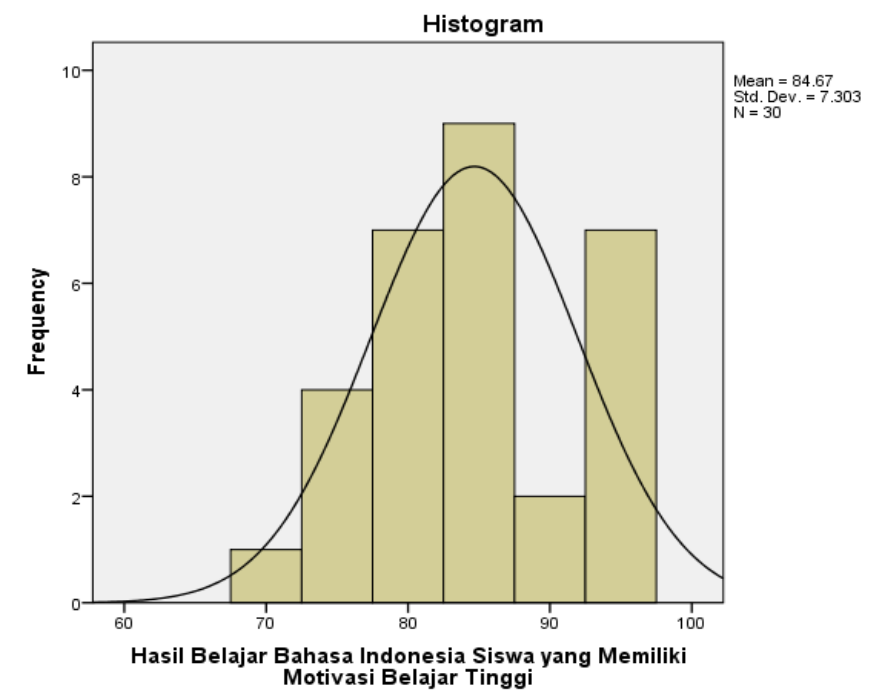

Gambar 3. Histogram Poligon Variabel Hasil Beljaar Bahasa Indonesia yang Memiliki Motivasi Belajar Tinggi

Data Hasil Belajar Bahasa Indonesia yang Memiliki Motivasi Belajar Rendah (B)

Tabel 4. Deskripsi Data Penelitian Hasil Belajar Bahasa Indonesia yang Memiliki Motivasi Belajar Rendah

\section{Statistics}

Hasil Belajar Bahasa Indonesia Siswa yang Memiliki Motivasi Belajar Rendah

\begin{tabular}{|c|c|c|}
\hline \multirow{2}{*}{$\mathrm{N}$} & Valid & 30 \\
\hline & Missing & 30 \\
\hline Mean & & 75.17 \\
\hline Median & & 75.00 \\
\hline Mode & & 75 \\
\hline Std. Deviation & & 6.226 \\
\hline Minimum & & 65 \\
\hline Maximum & & 85 \\
\hline
\end{tabular}

Bila dilihat dari hasil perhitungan di atas, maka bisa dikatakan bahwa Hasil Belajar Bahasa Indonesia yang memiliki motivasi belajar rendah di SMP Swasta di Kabupaten Indramayu tergolong cukup. Hal ini diindikasikan dengan perolehan 
nilai rata-rata sebesar 75.17. Untuk memperjelas data di atas, dijelaskan dalam histogram sebagai berikut:

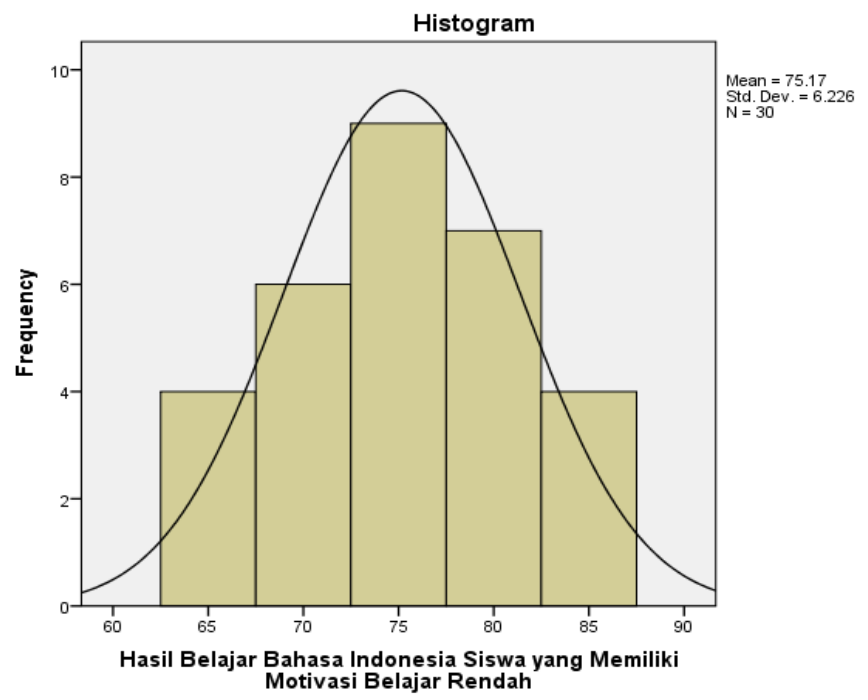

Gambar 4. Histogram Poligon Variabel Hasil Belajar Bahasa Indonesia yang Memiliki Motivasi Belajar Rendah

Data Rangkuman kelompok $A_{1} B_{1}, A_{1} B_{2}, A_{1} B_{1}$, dan $A_{2} B_{1}$

Rangkuman data hasil penelitian sesuai dengan rangcangan penelitian seperti tertera dalam table di bawah ini:

Tabel 5. Rangkuman Statistik Deskriptif

\begin{tabular}{|c|c|c|c|c|}
\hline \multicolumn{5}{|l|}{ Descriptive Statistics } \\
\hline \multicolumn{5}{|c|}{ Dependent Variable: Hasil Belajar Bahasa Indonesia } \\
\hline Model Pembelajaran & Motivasi Belajar & Mean & Std. Deviation & $\mathrm{N}$ \\
\hline \multirow{3}{*}{ Jigsaw } & Tinggi & 88.67 & 6.114 & 15 \\
\hline & Rendah & 75.67 & 6.230 & 15 \\
\hline & Total & 82.17 & 8.972 & 30 \\
\hline \multirow{3}{*}{ Konvensional } & Tinggi & 80.67 & 6.230 & 15 \\
\hline & Rendah & 74.67 & 6.399 & 15 \\
\hline & Total & 77.67 & 6.915 & 30 \\
\hline \multirow{3}{*}{ Total } & Tinggi & 84.67 & 7.303 & 30 \\
\hline & Rendah & 75.17 & 6.226 & 30 \\
\hline & Total & 79.92 & 8.259 & 60 \\
\hline
\end{tabular}

Berdasarkan data di atas, diperoleh data bahwa untuk hasil belajar Bahasa Indonesia yang menggunakan model pembelajaran Jigsaw dan memiliki motivasi belajar tinggi terdiri dari 15 peserta didik memiliki nilai rata-rata 88.67 dan standar deviasi 6.114. Untuk hasil belajar Bahasa Indonesia yang menggunakan model pembelajaran Jigsaw dan memiliki motivasi belajar rendah terdiri dari 15 peserta didik memiliki nilai rata-rata 75.67 dan standar deviasi 6.230. Untuk hasil belajar 


\section{Diskursus: Jurnal Pendidikan Bahasa Indonesia}

Vol. 1, No. 2, Agustus 2018, pp. 165-177

p-ISSN: 2615-4935

e-ISSN: 2615-4943

Bahasa Indonesia yang menggunakan model pembelajaran konvensional dan memiliki motivasi belajar tinggi terdiri dari 15 peserta didik memiliki nilai rata-rata 80.67 dan standar deviasi 6.230. Untuk hasil belajar Bahasa Indonesia yang menggunakan model pembelajaran konvensional dan memiliki motivasi belajar rendah terdiri dari 15 peserta didik memiliki nilai rata-rata 74.67 dan standar deviasi 6.399 .

Tabel 6. Deskripsi Statistik menurut Rancangan Penelitian

\begin{tabular}{|c|c|c|c|c|}
\hline \multirow[t]{2}{*}{ B } & \multirow[t]{2}{*}{ Stat } & \multicolumn{2}{|l|}{$\mathbf{A}$} & \multirow[t]{2}{*}{ Total } \\
\hline & & $A_{1}$ & $\mathbf{A}_{2}$ & \\
\hline \multirow{3}{*}{$\mathrm{B}_{1}$} & $\mathrm{n}$ & 15 & 15 & 30 \\
\hline & $\hat{X}$ & 88.67 & 80.67 & 84.67 \\
\hline & $\mathrm{s}$ & 6.114 & 6.230 & 7.303 \\
\hline \multirow{3}{*}{$\mathrm{B}_{2}$} & $\mathrm{n}$ & 15 & 15 & 30 \\
\hline & $\hat{X}$ & 75.67 & 74.67 & 75.17 \\
\hline & $\mathrm{s}$ & 6.230 & 6.399 & 6.226 \\
\hline \multirow{3}{*}{ Total } & $\mathrm{n}$ & 30 & 30 & 60 \\
\hline & $X$ & 82.17 & 77.67 & 79.92 \\
\hline & $\mathrm{s}$ & 8.972 & 6.915 & 8.259 \\
\hline
\end{tabular}

Uji Persyaratan Analisis Data

Uji Normalitas

Tabel 7. Uji Normalitas Data A1, A2, B1, dan B2

\begin{tabular}{|c|c|}
\hline \multicolumn{2}{|c|}{ One-Sample Kolmogorov-Smirnov Test } \\
\hline & Hasil Belajar Bahasa Indonesia \\
\hline $\mathrm{N}$ & 60 \\
\hline \multirow{2}{*}{ Normal Parameters ${ }^{\mathrm{a}, \mathrm{b}}$} & 79.92 \\
\hline & 8.259 \\
\hline \multirow{3}{*}{ Most Extreme Differences } & .129 \\
\hline & .129 \\
\hline & -.104 \\
\hline Kolmogorov-Smirnov Z & 1.002 \\
\hline Asymp. Sig. (2-tailed) & .268 \\
\hline \multicolumn{2}{|l|}{ a. Test distribution is Normal. } \\
\hline \multicolumn{2}{|l|}{ b. Calculated from data. } \\
\hline
\end{tabular}

Berdasarkan tabel tersebut menunjukkan bahwa nilai uji statistik Kolmogorov-Smimov Z $=1.002$ dan nilai Sig.0.268 > 0,05. Hal ini memiliki arti bahwa semua data di atas berdistribusi normal.

\section{Uji Homogenitas}

Pengujian homogenitas pada data model pembelajarandilakukan dengan uji Levene's pada taraf signifikansi $5 \%$.

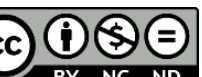


Tabel 8. Uji Homogenitas

\begin{tabular}{|l|l|l|l|}
\hline \multicolumn{4}{|l|}{ Levene's Test of Equality of Error Variances $^{\mathbf{a}}$} \\
\hline Dependent Variable: & Hasil Belajar Bahasa Indonesia \\
\hline F & df1 & df2 & Sig. \\
\hline .110 & 3 & 56 & .954 \\
\hline
\end{tabular}

Tests the null hypothesis that the error variance of the dependent variable is equal across groups.

a. Design: Intercept $+\mathrm{A}+\mathrm{B}+\mathrm{A} * \mathrm{~B}$

Dari tabel di atas diperoleh data $\mathrm{Fh}=0.110$ dan Sig. $=0.954>0,05$. Hal ini memiliki pengertian bahwa data berasal dari sampel yang homogen. Dengan demikian hipotesis nol diterima. Ini berarti sampel berasal dari populasi yang memiliki varians yang sama (homogen). Hal ini berlaku dari pengujian normalitas dan homogenitas di atas dapat disimpulkan bahwa persyaratan yang harus dipenuhi oleh data penelitian yang akan diolah dengan teknik ANOVA sudah terpenuhi.

\section{Uji Hipotesis}

Analisis terhadap data hasil belajar peserta didik dilakukan dengan menggunakan ANOVA dua arah yang pekerjaan rumahocess perhitungannya di bantu dengan pekerjaan rumahogram SPSS 20. Hasil uji ANOVA tersebut kemudian dilanjutkan dengan uji $\mathrm{F}$ untuk mengetahui signifikansi perbedaan diantara masing-masing kelompok secara signifikan (simple effect). Dengan kata lain, uji $\mathrm{F}$ digunakan dengan tujuan untuk melihat kelompok sampel mana yang lebih tinggi Hasil Belajar Bahasa Indonesia siswa ditinjau dari model pembelajaran dan motivasi belajar.

Ringkasan hasil analisis data dengan menggunakan ANOVA dapat dilihat pada tabel berikut:

Tabel 9. Uji Hipotesis Penelitian

\begin{tabular}{|c|c|c|c|c|c|}
\hline \multicolumn{6}{|c|}{ Tests of Between-Subjects Effects } \\
\hline \multicolumn{6}{|c|}{ Dependent Variable: Hasil Belajar Bahasa Indonesia } \\
\hline Source & Type III Sum of Squares & $\mathrm{Df}$ & Mean Square & $\mathrm{F}$ & Sig. \\
\hline $\begin{array}{l}\text { Corrected } \\
\text { Model }\end{array}$ & $1841.250^{\mathrm{a}}$ & 3 & 613.750 & 15.742 & .000 \\
\hline Intercept & 383200.417 & 1 & 383200.417 & 9828.652 & .000 \\
\hline A & 303.750 & 1 & 303.750 & 7.791 & .007 \\
\hline $\mathrm{B}$ & 1353.750 & 1 & 1353.750 & 34.722 & .000 \\
\hline$A * B$ & 183.750 & 1 & 183.750 & 4.713 & .034 \\
\hline Error & 2183.333 & 56 & 38.988 & & \\
\hline Total & 387225.000 & 60 & & & \\
\hline Corrected ' & 14024.583 & 59 & & & \\
\hline
\end{tabular}

Berdasarkan data di atas, maka hipotesis penelitian yang diajukan dapat terjawab. Adapun penjelasan mengenai table di atas adalah sebagai berikut: 
Hipotesis Pertama: terdapat pengaruh yang signifikan model pembelajaran terhadap Hasil Belajar Bahasa Indonesia di SMP Swasta di Kabupaten Indramayu.

Berdasarkan table 4.12 diperoleh hasil Anova dengan nilai Sig. $=0,007<$ 0,05 dan $\mathrm{Fh}=7.791$, maka hipotesis nol $(\mathrm{Ho})$ ditolak dan hipotesis alternative $\left(\mathrm{H}_{1}\right)$ diterima. Hal ini memiliki arti bahwa terdapat pengaruh yang signifikan model pembelajaran terhadap Hasil Belajar Bahasa Indonesia SMP Swasta di Kabupaten Indramayu, atau dengan kata lain, tidak terdapat perbedaan Hasil Belajar Bahasa Indonesia yang menggunakan model pembelajaran Jigsaw dengan yang menggunakan model pembelajaran konvensional.

Hipotesis Kedua: terdapat pengaruh yang signifikan motivasi belajar terhadap Hasil Belajar Bahasa Indonesia di SMP Swasta di Kabupaten Indramayu.

Berdasarkan table 4.12 diperoleh hasil Anova dengan nilai Sig. $=0.000<$ 0.05 dan $\mathrm{Fh}=34.722$, maka hipotesis nol $(\mathrm{Ho})$ ditolak dan hipotesis alternative $\left(\mathrm{H}_{1}\right)$ diterima. Hal ini memiliki arti bahwa terdapat pengaruh yang signifikan motivasi belajar terhadap Hasil Belajar Bahasa Indonesia di SMP Swasta di Kabupaten Indramayu. Atau dengan kata lain, terdapat perbedaan yang menggunkan motivasi belajar tinggi dengan yang motivasi belajar rendah.

Hipotesis Ketiga: terdapat pengaruh interaksi yang signifikan model pembelajaran dan motivasi belajar terhadap Hasil Belajar Bahasa Indonesia di SMP Swasta di Kabupaten Indramayu.

Berdasarkan tabel 4.12 diperoleh hasil Anova dengan nilai Sig. $=0,034<$ 0,05 dan $\mathrm{Fh}=4.713$, maka hipotesis nol $(\mathrm{Ho})$ ditolak dan hipotesis alternative $\left(\mathrm{H}_{1}\right)$ diterima. Hal ini memiliki arti bahwa terdapat pengaruh interaksi yang signifikan model pembelajaran dan motivasi belajar terhadap Hasil Belajar Bahasa Indonesia SMP Swasta di Kabupaten Indramayu.

Sementara itu, nilai Adjusted R. Squared sebesar 0.358 memiliki arti bahwa model pembelajaran dan Hasil Belajar Bahasa Indonesia memberikan pengaruh sebesar 35,8\% terhadap peningkatan Hasil Belajar Bahasa Indonesia SMP Swasta di Kabupaten Indramayu.

\section{Uji Lanjut}

Untuk mengetahui sejauh mana interaksi model pembelajaran dan motivasi belajar terhadap Hasil Belajar Bahasa Indonesia, maka dilakukan uji lanjutan. Adapun uji lanjutan yang dipakai adalah uji Tukey.

Tabel 10. Tabel Uji Lanjut

\section{Multiple Comparisons}

Dependent Variable: Hasil Belajar Bahasa Indonesia

Tukey HSD

\begin{tabular}{|l|l|l|l|lr|}
\hline (I) & (J) & Mean & Std. Error & Sig. & $\begin{array}{r}95 \% \\
\text { Interval }\end{array}$ \\
Post Hoc & Post Hoc Difference & & Confidence \\
\hline
\end{tabular}


Diskursus: Jurnal Pendidikan Bahasa Indonesia

Vol. 1, No. 2, Agustus 2018, pp. 165-177

p-ISSN: 2615-4935

e-ISSN: 2615-4943

\begin{tabular}{|l|l|l|l|l|l|l|}
\hline & & $(\mathrm{I}-\mathrm{J})$ & & \multicolumn{2}{|c|}{ Lower Bound } & Upper Bound \\
\hline \multirow{4}{*}{ A1B1 } & A1B2 & $13.00^{*}$ & 2.280 & .000 & 6.96 & 19.04 \\
\cline { 2 - 7 } & A2B1 & $8.00^{*}$ & 2.280 & .005 & 1.96 & 14.04 \\
\cline { 2 - 7 } & A2B2 & $14.00^{*}$ & 2.280 & .000 & 7.96 & 20.04 \\
\hline \multirow{5}{*}{ A1B2 } & A1B1 & $-13.00^{*}$ & 2.280 & .000 & -19.04 & -6.96 \\
\cline { 2 - 7 } & A2B1 & -5.00 & 2.280 & .138 & -11.04 & 1.04 \\
\cline { 2 - 7 } & A2B2 & 1.00 & 2.280 & .972 & -5.04 & 7.04 \\
\hline \multirow{5}{*}{ A2B1 } & A1B1 & $-8.00^{*}$ & 2.280 & .005 & -14.04 & -1.96 \\
\cline { 2 - 7 } & A1B2 & 5.00 & 2.280 & .138 & -1.04 & 11.04 \\
\cline { 2 - 7 } & A2B2 & 6.00 & 2.280 & .052 & -.04 & 12.04 \\
\hline \multirow{3}{*}{ A2B2 } & A1B1 & $-14.00^{*}$ & 2.280 & .000 & -20.04 & -7.96 \\
\cline { 2 - 7 } & A1B2 & -1.00 & 2.280 & .972 & -7.04 & 5.04 \\
\cline { 2 - 6 } & A2B1 & -6.00 & 2.280 & .052 & -12.04 & .04 \\
\hline
\end{tabular}

Berdasarkan uji lanjut di atas, dapat disimpulkan sebagai berikut:

Pada kelompok A1B1 dan A1B2 terlihat bahwa Mean Difference sebesar 13.00, artinya selisih antara rata-rata kelompok A1B1 dan A1B2 sebesar 13.00. Nilai ini cukup besar dan dapat dibuktikan dengan nilai signifikansi $0,000<0,05$, atau dapat diartikan bahwa khusus untuk kelompok A1, terdapat perbedaan yang signfikan Hasil Belajar Bahasa Indonesia antara kelompok B1 dan B2.

Pada kelompok A1B1 dan A2B1 terlihat bahwa Mean Difference sebesar 8.00, artinya selisih antara rata-rata kelompok A1B1 dan A2B1 sebesar 8.00. Nilai ini cukup besar dan dapat dibuktikan dengan nilai signifikansi $0.005<0,05$, atau dapat diartikan bahwa khusus untuk kelompok B1, terdapat perbedaan yang signfikan Hasil Belajar Bahasa Indonesia antara kelompok A1 dan A2.

Pada kelompok A1B2 dan A2B2 terlihat bahwa Mean Difference sebesar 1.00; artinya selisih antara rata-rata kelompok A1B2 dan A2B2 sebesar 1.00. Nilai ini cukup kecil dan dapat dibuktikan dengan nilai signifikansi $1.000>0.05$; atau dapat diartikan bahwa khusus untuk kelompok B2, terdapat perbedaan yang tidak signfikan Hasil Belajar Bahasa Indonesia antara kelompok A1 dan A2.

Pada kelompok A2B1 dan A2B2 terlihat bahwa Mean Difference sebesar 6.00, artinya selisih antara rata-rata kelompok A2B1 dan A2B2 sebesar 6.00. Nilai ini cukup besar dan dapat dibuktikan dengan nilai signifikansi $0.052>0.05$; atau dapat diartikan bahwa khusus untuk kelompok A2, terdapat perbedaan yang tidak signifikan Hasil Belajar Bahasa Indonesia antara kelompok B1 dan B2.

\section{SIMPULAN}

Berdasarkan hasil uji hipotesis dapat ditarik kesimpulan sebagai berikut:

1. Terdapat pengaruh yang signifikan model pembelajaran terhadap hasil belajar Bahasa Indonesia siswa SMP Swasta di Kabupaten Indramayu. Hal ini dibuktikan dengan perolehan Sig. $=0,007<0,05$ dan $\mathrm{Fh}=7.791$.

2. Terdapat pengaruh yang signifikan motivasi belajar terhadap hasil belajar Bahasa Indonesia siswa SMP Swasta di Kabupaten Indramayu. Hal ini dibuktikan dengan perolehan Sig. $=0.000<0.05$ dan $\mathrm{Fh}=34.722$.

3. Terdapat pengaruh interaksi yang signifikan model pembelajaran dan motivasi belajar terhadap hasil belajar Bahasa Indonesia siswa SMP Swasta di 
Diskursus: Jurnal Pendidikan Bahasa Indonesia

Vol. 1, No. 2, Agustus 2018, pp. 165-177

p-ISSN: 2615-4935

e-ISSN: 2615-4943

Kabupaten Indramayu. Hal ini dibuktikan dengan perolehan Sig. $=0,034<0,05$ dan $\mathrm{Fh}=4.713$.

\section{DAFTAR PUSTAKA}

Ibnudin. (2018). Metode penelitian. Retrieved from Ibnudin.net website: http://ibnudin.net/category/my-

Lie, A. (2005). Cooperatif learning. Jakarta: Gramedia Widiasarana Indonesia.

Saksomo. (2004). Strategi belajar mengajar. Jakarta: Bina Aksara.

Sugiyono. (2008). Metode penelitian kuantitatif kualitatif dan $R \& D$. Bandung: Alfabeta. 